\title{
Variety of Coastal Ornaments in Aceh: Aesthetic Phenomena in the Continuation of History and Culture
}

\author{
Bukhari, Aulia Rahman, Mufti Riyani \\ History Study Program, Samudra University, Langsa, Aceh, Indonesia \\ bukhari@unsam.ac.id
}

\begin{abstract}
Focusing on the study of historical artifacts of art found in the Aceh Coastal region, this study seeks to analyze ornamental diversity as an aesthetic phenomenon that has a meaningful relationship with 1. Continuation of history, 2. Links in the search for cultural identity, and 3 Balancing cultural values in Acehnese society. Throughout history, the art of embroidering gold threads, woven silk fabrics, stabbing weapons, jewelry art, and wood carvings have been the hallmark of Aceh beach crafts that in their development consistently used their identity motifs. The intended identity motif is a motif that shows the cosmopolitanism of Aceh regarding pre-Islamic cultural influences and influences originating from friendly countries. The diplomatic relations which brought the influence of Persia and the Moghul dynasty from India occurred at the golden peak of Aceh's art history, especially during the times of Iskandar Muda and Iskandar Thani, although in the end, the clearest artistic trend emerged, namely all Islam. Aceh's design patterns in a stylish form become geometric shapes. The characteristic of decoration in the coastal communities of Aceh is influenced by Arabic concepts, is the development of a sense of beauty that is free from natural myths and is done by developing abstract patterns taken from floral motifs, foliage shaped and polygon shapes as a process of balancing cultural values.
\end{abstract}

Keywords

culture; aesthetic

phenomena;

historical continuity;

ornamental varieties

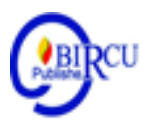

\section{Introduction}

The use of ornamental varieties as symbols of cultural identity in a society is in harmony with human nature as a symbol of homo. Decorative variations in applications in the decorative field can be stylish (stylized or arranged) so that the shape can vary greatly. But this stylization process is inseparable from the basic form of decorative variants called motifs. The motive is the basic element of ornamentation that characterizes cultural identity. Sunaryo (2009: 14) mentions:

"Motifs are the main elements of an ornament. Through motives, themes or basic ideas an ornament can be controlled because the embodiment of motifs is generally a composition of forms in nature or manifestations of representations seen from nature. There will also be some that are only imaginary results because they are imaginative even cannot be recognized, the motive then called abstract form.

The application of ornamental varieties is spread across various results of human activities from their past. Thus, history as a human activity leaves traces one of them on objects created or modified by humans. Some of these relics can be moved and are usually 
called Artifacts. As a cultural object, artifacts display the cultural form and cultural values of the community as its creator.

In anthropological studies, artifacts are a form of physical culture in the form of the results of the activities, actions and work of all humans in society in the form of objects and objects that can be touched, seen and documented. Artifacts are art objects or contain elements of art. Objects with elements of art generally contain elements of pure art and applied art. Pure art has a branch of art in the form of painting and carving while on the other hand the applied art is usually manifested in crafts or crafts.

Aceh is a unique community unit with artistic wealth. The history of forging Aceh as an area that has special characteristics is able to display its identity in the archipelago. Based on language and social archetypes, Aceh belongs to the people of Sumatra and Southeast Asia, but Aceh has special characteristics in the form of culture that emerged from the coastal kingdoms formed during the four centuries that ward off foreign domination. One of the unique identities of the Acehnese is embodied in the form of ornaments symbolized by the royal seal nine times (sikureueng stamp) and also appears in stories and poetry (Reid, Anthony. 2011: 336).

\section{Research Method}

The method used in this research is the historical critical method. Starting from heuristic activities or searching for historical traces, sources of criticism, interpretation and ending with historiography activities. In the first stage, heuristics are carried out with the main source in the form of artifacts (assisted with sources in the form of documentation of artifacts). The search was carried out on Aceh Ornaments scattered in the distinctive art of the Aceh coast, which consisted of jewelry, gold thread embroidery, silk weaving crafts, stabbing weapons and wood and stone carvings. Searches were carried out in several places including the Aceh Nagari Museum, the Samudra Pasai Museum, the Rumoh Aceh Langsa City Protected Forest Park and individually owned collections. As another reference material, a collection of well-documented Aceh artifacts is traced to archives stored at the Aceh Documentation and Information Center (PDIA). Among his documentation, a book by Harun Keuchik Leumik (1998) titled Aceh Traditional Jewelry which contains images of Aceh artifacts with exceptional quality, consisting of various ornaments in jewelry, stabbing weapons, ceramics, and woven cloth to currencies. In addition, the Aceh Provincial Adat Council (MAA) documentation in the form of the Aceh Motifs collection is a valuable resource. Documents owned by industrial services in the Province of the Special Region of Aceh in 1992 contained various Aceh songket motifs from past motifs that complement the documentation in Barbara Leigh's book and ornamental art ornaments in Aceh (reproduced by Industry agents).

The collected data is then tested for its validity and credibility through external and internal criticism. Data that has been tested becomes the distribution of facts analyzed by the connection. Finally, the results of interpretation are then presented in written form commonly called historiography.

\section{Result and Discussion}

Mapping ornamental varieties will be easier to understand by grouping basic characteristics and motifs in each region. Before discovering the mapping of Aceh's 
ornamental diversity, we can classify the geographical nature of culture in Acehnese society which ethnographically consists of agricultural communities and fishing communities. Previous research (T. Junaidi and Mufti Riyani, 2016) produced a mapping of the Aceh region as an area with the characteristics of a Fishermen and Farmers Community, although some regions have multiple identities or are mixed between the two.

Based on research data, it can be seen that several districts / regions in Aceh represent Aceh's decorative motifs. The document in question was found by researchers at the home of one of the sources (Ms. Mariana, Ulee Madoon Village, North Aceh with conditions without publishers and writers; there is a possibility that the Aceh Provincial Decranasda document titled Aceh Ornamental Art) Ornament Motives compiled in 2002, before the Tsunami ).

The document shows that several districts in Aceh such as; Aceh Besar Regency, Pidie Regency, North Aceh Regency, East Aceh Regency, Central Aceh Regency, West Aceh Regency, South Aceh Regency, and Southeast Aceh Regency are areas in Aceh that have distinctive ornamental motifs. Decorative motifs developed from the basic motifs typical of the area concerned. However, there are some regions that develop decorative items with the same basic motifs.

The basic motifs of Aceh Besar are the basic motifs that are widely used in several other areas which include the Pidie, North Aceh and East Aceh regions. While Central Aceh, West Aceh, South Aceh, and Southeast Aceh have their own basic motives, although some have the same basic motives with different names or the same names with different forms.

The basic motifs in Aceh Besar Regency consist of gigo darut (grasshopper teeth), pucuk reubong, oun (leaves), oun labu (pumpkin leaves), oun ubi (sweet potato leaves), bungong kepula (cape), bungoung jeumpa, bungoung seulanga, bungong meulu (jasmine flower), puta talo (turning rope), bah aneuh (pineapple), sisik naga, paku oun (fern), talo i.e. (water cord), bulan bintang, awan meucanek (lined clouds), meuputa talo , rante, bungong oak leuk. The following is a sketch of each basic motif:
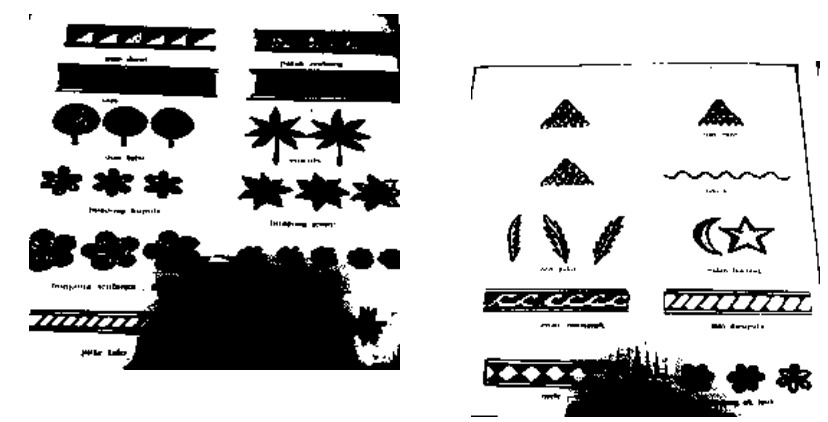

Figure 1. Basic Motives in Aceh Besar Regency Source: Aceh's ornamental art motif document. Nonim: p. 3-4

As explained earlier, the North Aceh, Pidie and East Aceh regions have similar basic motifs but in the North Aceh region there are also basic motifs that are widely used and characterized. The motif is the sunflower motif which is widely applied as various ornaments in various fields, cloth, wood and other fields. Following this is the wind movement (carving on the roof of the house) and the door at the official residence of the North Aceh regent. 


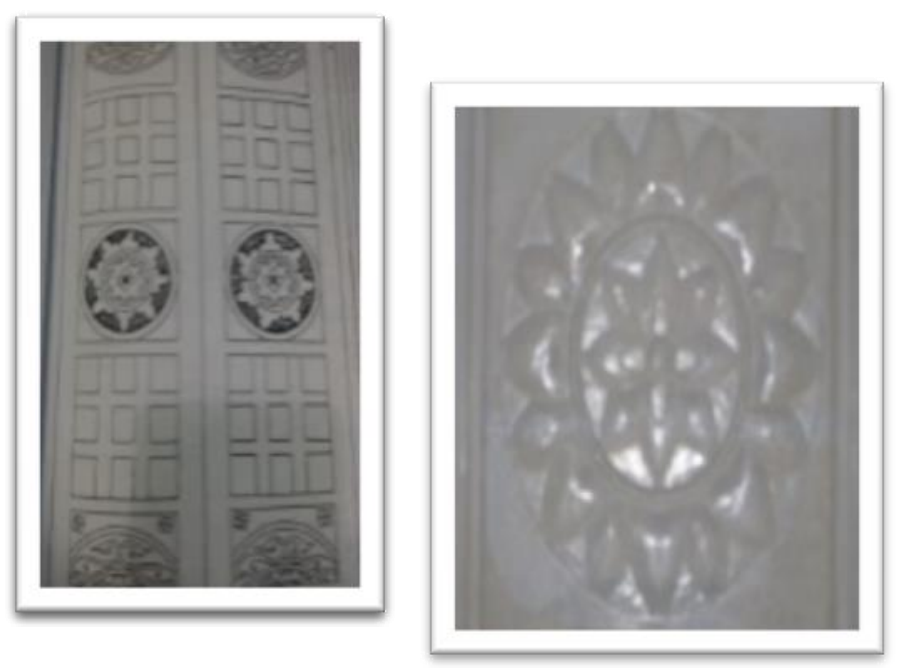

Figure 2. Motive at the official residence of the North Aceh regent Source: right , Aceh ornament motif; 52), left (personal documentation).

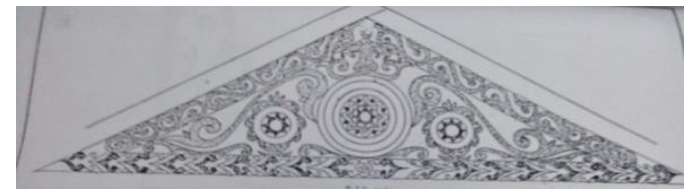

Figure 3. Motive of the wind (wind) on the roof of the official residence of the North Aceh regent

Source: Aceh ornament motif; 56).

As for the Pidie and Aceh regions, although other basic motifs are also applied, the basic motifs that most often emerge are the basic motifs of the moon which are arranged into other motifs such as awan meucanek, keupula flowers, leaves (oun). This motif is widely used as decoration on kasab, which is a craft using gold thread embroidery. Aceh Besar and Pidie are two regions which are the centers or centers of craftsmen. The results of Kasab can be in the form of $d u k$ (seat cushion), angkin (mosquito net decoration), kipah (fan), tiree (curtain), langeh-langeh (ceiling decoration ceiling).

The basic motifs of Aceh Besar are the basis for the basic motifs in northern Aceh, Pidie and East Aceh with application characteristics that distinguish them from other regions. Cut Huzaimah, the resource person who is the head of the Putro Phang division in the Aceh Langsa Customary Council, confirmed the statement by stating that these regions have similar characteristics, especially for the East Aceh region. The difference between these 3 big regions is the size or size of the basic motif and whether or not there is a margin on the basic motif.

Furthermore, the speakers distinguished 3 large areas classified into large areas of Aceh's decorative diversity with coastal and inland characteristics with the characteristics of the cultivation community (Interview with $\mathrm{Hj}$. Cut Huzaimah, June 1, 2016) consisting of:

1. The North Coast Region, including Aceh Tamiang, Lhokseumawe, Langsa City, Beureuen, Banda Aceh and Sigli (the capital of Pidie). Although Sigli is grouped on the north coast but it has a style that is quite striking with other regions. Whereas regions with very identical decoration styles are owned by three regions, namely Beureuen-North Aceh, Lhokseumawe and Langsa City in East Aceh. 
2. The South Coast Region, including Meulaboh (in the previous mapping it could be grouped in West Aceh) and Tapaktuan

3. Rural Areas (fields and forests): Southeast Aceh, Central Aceh and Lokop (Administratively located in East Aceh but culturally a sub-culture of Gayo lue in Southeast Aceh and originating from Central Aceh).

In the study of political history, the north coast is usually referred to as the East coast (Sumatra) and the south coast is called the West Coast (Sumatra). In the study of ornamental varieties, especially in making motifs on cloth, the north and south coast are distinguished in the form of embroidery and embroidery on the outside. In deep embroidery, there is a borderline as the basic pattern, whereas in the southern coast region, embroidery is not given a margin that marks the basic pattern.

The naming of regional groups is often different. According to the socio-cultural grouping, population distribution in the Special Region of Aceh is divided into areas of the north and east coast, west and south coast and inland areas in Central and Southeast Aceh. The population distribution in the Aceh region is indeed uneven. In general, the population is more focused on areas that are already open even though the resource potential is relatively low. About two-thirds of the population lives on the plains along the north and east coasts. While others inhabit the west and south coast regions, as well as the central and southeastern parts of Aceh (Ibrahim Hasan, 1979; 5; Hariri Hadi, 1972: 24 in the Ministry of Education and Culture 1983: 26).

\subsection{Continuation of History}

Chronologically, the periodization of Aceh History is known as 3 distinct historical periods, namely the history of the Islamic culture of Samudra Pasai and Lamuri and the culture of Aceh Darussalam (Deddy Satria, 2016: 1 arabesque). But of these three phases, the historical development of Aceh's decorative designs has remained connected with decorative motifs in the past both the pre-historical and Hindu-Buddhist periods with some evidence of archaeological remains studied by many historians and archeologists.

Determining the beginning when the form of handicrafts carried out by native Acehnese as their own creation is difficult to ascertain. But although it does not refute the opinion of Berbara Leigh (1989: 6.) which states that during this period there was a destructive act of cultural art patterns at the time, as an attempt to clarify the elements of 'jahiliya', but as cultural activities and Sufistic characters, thick in Acehnese society, a number of decorative styles from the past were absorbed into Islam.

Historical continuity in Aceh's decorative types, specifically Aceh's coastline, is demonstrated by the continued appearance of decorative links between these times. Based on archeological research, pre-historic and Hindu style ornamental patterns can still be found in Islamic artifacts. Laila Abdul Jalil (2013: 136) shows evidence of the appearance of Makara carvings and lotus petal motifs.

Kala Makara is a motif carved into the temple building, especially on the temple door that functions as an exorcist or bad element. During the Islamic period in Aceh, the form when Makara was seen on a flat winged headstone, or was called by Muarif Ambari (1998) with the term buffalo head motif (Bucran aile). In a previous study, Ambari (1984) divided the design in more detail into "buffalo horn" (Fr; bucrane) and buffalo head (bucrance). In some traditional communities in Indonesia, buffalo has an important meaning related to religious ceremonies 
In addition to the Makara type, pre-Islamic motifs that continue to this day are lotus flower motifs or in Sanskrit known as Padma. In Buddhist belief, lotus is a symbol of eternity. In the gravestone sculpture found by archaeologists in Aceh, there is a lotus motif that is carved simply and attractively in an eight-type club. The eight-mace type is a symbol or is considered a male figure (Abdul Jalil, 2013: 138). The use of the Mace design at the same time shows similarities to the concept of phallus in Hindu beliefs with the same meaning.

Furthermore, Abdul Jalil assumed that interestingly carved lotus motifs were usually used at the tombs of kings or aristocrats. While a simpler motif is used for the graves of scholars. The use of this motif on the tomb of the ulema is possible to be relevant to the concept of Islamic society which makes the ulema as a figure whose knowledge will remain eternally remembered. This motif is usually applied to the top of the headstone. The form of padma used by the bearers of Hindu culture consists of several forms, both buds, buds and with a crown of bloom.

In another comparative study, Leigh (1989) by observing Robert Wesing's analysis of the Gunongan building, he sees it in the perspective of art history. The fold applied to Gunongan is very similar to the lotus shape (Leight, Barbara.1989: 9).

Application of lotus motifs in other decorative fields: woven cloth etc.

Another influence that I can catch is the emergence of a motif that shows a peacock. This motif appears in gold thread embroidery crafts found in West Aceh. Peacock is one of the creatures that is conceptualized as a creature of nirvana and is identical to Lord Vishnu.

The picture of the peacock motif:

In the explanation above, between the Pasai-Lamuri period and the Aceh period, it has relevance, especially in the old decorative patterns (pre-Islamic patterns) such as the lotus motif and the buffalo head motif. Sunflower motifs that symbolize greatness and courage are also used in Buddhist beliefs as symbols of greatness and constitution. In Islamic times, sunflower motifs were used as ornaments carved in stone or wood like those found in graves in the kingdom of Aceh Darussalam. Applications of sunflower motifs that adorn the official residence of the North Aceh regent have been displayed at the top of this paper.

In addition to the motifs mentioned above, the cloud motif that is commonly applied to Aceh's beach decoration is a continuation of the Javanese-Hindu building art tradition and cannot be separated in its application with the mountain motif as a complement to the natural image of gods. Cloud motifs are also found in the tombstone of the Aceh Darussalam period, mentioned by Dahlia (2014: 64) that the 12th grave with a cloud flower motif dominates the ornaments on the headstone body and cross section. The meucanek cloud motif (in other regional terms called mega clouds) shows that clouds are closely related to water that symbolizes fertility. Clouds are also very famous in the Islamic concept as proof of God's greatness, the Lord of the universe also functions as a symbol of the resurrection day. The verses in the Qur'an mention a lot about clouds, one of which is verse 9 Fathir which means: 'Allah, $\mathrm{He}$ is the one who sends the wind and moves the clouds to the dead country, then we turn the earth after his death with rain like that is the day of the resurrection'.

The use of other motifs such as braided ropes or in Aceh's ornamental variety is called the spinning rope ornamental motif (talo meuputa) which is a continuation of the gyre ornament pattern as one of the geometric motifs that have been known since prehistoric times. 

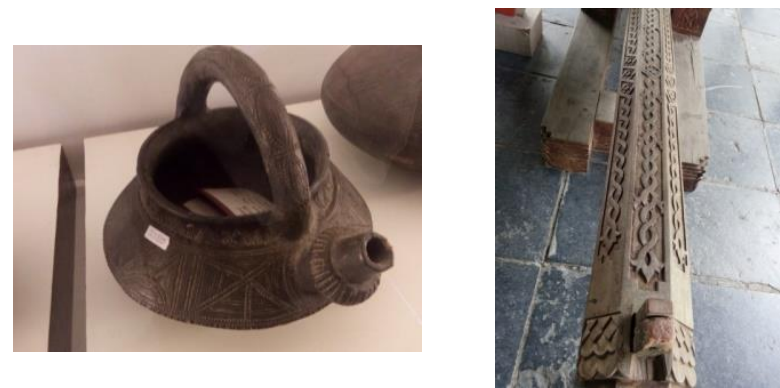

Figure 4. The application of rotary geometry motifs on art artifacts

Geometric motifs have very simple patterns such as woven patterns, zigzag lines, looping circles, triangles or other flat planes. In addition to geometric motifs in the shape of tortuous, banji, tumpal and circle are also widely applied from time to time. The circle has the meaning of perfection and is a depiction of the universe while rectangles and triangles are parables about human nature that cannot have perfection. Geometric motifs that are widely used in Aceh's decorative designs can also be observed in Hindu and Buddhist culture which are often used in temple buildings. Whereas the motif of the tumpal in the form of an isosceles triangle decorated with tendrils is often used as an edge decoration and is found as a top motif.

The tendrils as an old motif are still relevant to be used during Islam by describing them as virtues that are likened to seeds that are planted, growing into fertile trees which branch off and spread too many. These geometric motifs often decorate traditional houses, home furnishings, Kasab fabric crafts, embroidered clothing and even decorate rencong weapons.

The emergence of various ornamental plants has long been known in Indonesia. This condition is motivated by Indonesia's natural conditions which are rich in various types of flora. Therefore, in ornamental varieties apart from the realization of harmony in the previous period, the ornamental motifs of Aceh's plants also adopted various types of flora as places or plants that grew in this area.

\subsection{Links in the Search for Cultural identity}

Cosmopolitan Islamic beach decoration can be demonstrated through the adaptability and creativity of high-level local artists. This local genius appeared in the clearest artistic tendencies, as a result of obedience to Islamic teachings. The artistic tendency referred to is the Islamization of the overall design pattern of Aceh (Leight, Barbara, 1989: 7). The Islamization of Aceh's ornamentation into an Arabic motif is a combination of 3 elements, namely (1) geometric ornaments with a woven rope pattern that forms the ends, (2). Plants and plants, (3). Arabic characters, especially the letters 'ha' (ه) and 'lam' (ل) using the kufi pattern of the weaving pattern.

The search for Aceh's cultural identity by highlighting Islamic teachings and local wisdom emerged as a style of Arab influence itself. In addition to enriching forms, the search for cultural identity also appears in the technique of applying decorative motifs to Aceh.

The shape of the letters hu in ornamental calligraphy art, both expressed in sculptures and other forms of craft often turn into shapes such as plants such as stems and or flowers. The ability of Islamic artists to characterize a peace identity appears in the motifs of the letters which are transformed into plant shapes such as the letter $H u$ which transforms into leaves or flowers. 
$U$ hu 'or' huwa 'ornamental motif designs consist of rectangular geometric shapes combined with curved lines arranged symmetrically, then combined with various plant motifs such as leaves, flowers and buds. $\mathrm{U}$ hu motive 'is intended to do the word $u w a$ huwa' which comes from the Arabic letter 'ha', which means 'He' which is Allah SWT.

The 'lam' motif consists of two stems of flowers and leaves and buds. These lines are arranged to cross and rotate to form a weaving rope. Webbing ropes are arranged in a tiered shape with a smaller shape to the top. This matting can sometimes resemble an 'umbrella' or 'tree'. The design of this motif comes from the idea of cultivating Arabic letters or kufi khat in the form of plants. The letter 'lam' means rejection and absence; no, nothing else. Nothing is eternal except Allah: 'Allah Al Haya'. These two motifs are often carved together as the main letter of the word 'Allah'. (Immortal God of Life) (Deddy Satria).

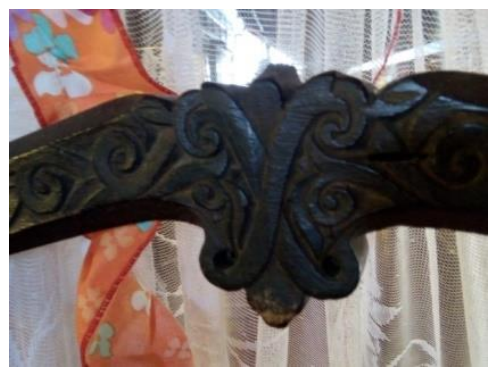

Figure 5. Image of the letter $\mathrm{Hu}$, lam, and Allah

The comparison with other decorative arts. Pictures of baby swings in the Aceh rumoh collection at the Aceh Nagari museum. It is possible to enrich lam letters

The development of ornamental motifs with writing techniques Arabic or Arabic letters also experienced development from the Islamic cultural phase of the Samudra Pasai phase, Lamuri to the Aceh Darussalam period. In the Pasai phase, characteristic motifs are widely used with many Islamic calligraphic designs using khat designs with rows of vertical lines similar to curtains for round and curved letters. (Deddy Satria, 2009: 89). Ornaments are usually carved on the head in the form of design motifs with decorative elements of plant leaves and flowers that form the figure of a 'soul bird' that is cultivated. The Soul Bird stands with wings outstretched. This symbol often appears in classical Persian Islamic texts as symbols and symbols of 'spirit' and 'soul' (Deddy Satria, 2016: 13).

\section{Image of soul bird}

The influence of Islam on the Lamuri phase motif has several different time periods. Some of the writings are based on 9th-12th century as recorded in Arabic, Chinese and Indian news. According to European, Arabic and Chinese records, it was also stated that in the 13th century 15 Lamuri had become Islamic. This is different from the Portuguese record which mentions it from the beginning of the 16th century AD The calligraphy engraving in this phase is marked by a stiff and stiff line or called nashi khat. In the following period, the characteristics of the Darussalam Darussalam motif motif were a continuation of the previous type but continued to experience significant developments especially in the decorative arts style and the use of Khat in Islamic calligraphy art.

with the composition of letters with vertical and horizontal lines, thick and thin, wide curved lines, the writing style of the Arabic letters is known as the khat ornamental style. The letters are then combined with other decorative motifs, especially plant elements such as leaves, flowers, buds and stems (Deddy Satria, arabesque number 2 ed IX). In this pattern, the decorative field is usually large so that the letters are placed following the decorative plane. 
Besides that, decorate Tsulut / Tsulut Prison. Also known as a type of tsulutsatin khat that is written closely and coincides with each other (Deddy Satria, Arabsek No 1:11) and several individual notes with the creator's creations.

\subsection{Balancing cultural values with the people of Aceh.}

The strongest foreign influence is the Persian influence and Indian influence. When Aceh was in its golden age, the Moghul kingdom in India became the ruling Islamic kingdom in South Asia. At almost the same time, the Ottoman Empire in Turkey reached its peak.

During the golden age of Aceh, gold threads were widely used, especially among the palace. Furthermore, the custom of using gold threads as clothing decoration materials and wall hangings might have been the cultural influence of the aristocrats from Moghul, India. Door decoration, cloth hanging room is an Indian influence that still exists today (Leight, Barbara: 1989: 30). However, the use of a variety of decorative motifs and sewing techniques that are local is proof that the people of Aceh have the power to balance high cultural values.

The people of West Aceh are called by Kreemer (1922) as the people who produce the most beautiful and quality embroidery of gold threads. Embossed sewing techniques (soft couching) to produce a 3-dimensional impression as well as the use of local materials such as coconut fibers (palm tree fibers) as yarn and add variations to the motifs are markers of local genius possessed by Acehnese people.

Rida Safuan Selian (2007) in the Garuda journal entitled Handicraft Embroidery of the Aceh Kasab Gold Thread (Study of Patterns and Functions of the Acehnese People) (portalgaruda.org.article.php, download 20 August 2016 at 9:00 pm)) states that the motives Kasab (synthesis of gold thread types) usually uses a form of flora and fauna that has been distilled or composed, the motif consists of the basic motifs mentioned earlier plus the motif of meuria scales (strawberry scales), udeung (shrimp), pigeon and goose motifs. But now fauna motifs are very rarely found. This is based on previous research because of the strong influence of Islam in the coastal areas of Aceh (Nurcholish Majdid, 2013: 127). While the strength of the moon motif in Kasab is basically the influence of the old pattern motif. The explanation can be seen in the following picture:

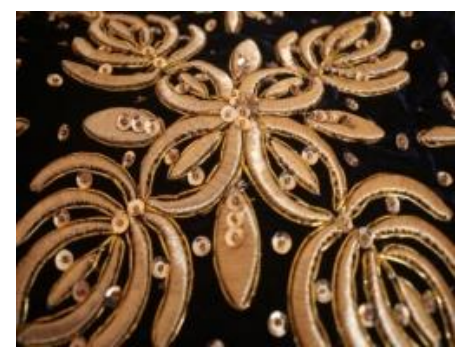

Figure 6. Check the typical Aceh Besar and Pidie duk

In addition to trade relations with the Moghul dynasty which caused an influence on Aceh's ornaments, relations between Aceh and Turkey or Persia were possible to begin with the King of Aceh during the reign of Sultan Al-Kahar (1537-1571) and officially continued until 1850 (Anthony Reid, 1969) Relationships this became very important in the mid-19th century, precisely in 1873 with the sending of Turkish reinforcements to drive out the Dutch colonials which would make annexation to the kingdom of Aceh Darussalam. The decorative elements of Persia or Turkey then sublimated Acehnese culture through its application to weapons and other handicraft items, especially those worn by men. 
Rencong is said to be heavily influenced by Persian ornaments. However, if traced back to history, rencong is a transformation of an awl that had existed in pre-Islamic times. Initially Rencong in subsequent developments, with the magnitude of the influence of Islam, rencong conceptualized as an embodiment of the phrase bismillah.

Rencong in the results of the study of Rafi Abdilah (2016) is the evolution of household appliances called sailors.

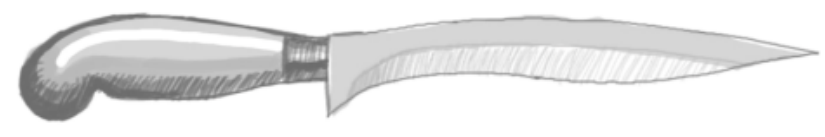

Figure 7. Peraut

It is possible to have an evolution with the addition of deeper basins or the term cugek in Aceh language which means basin. Sailors, in this phase change into the form of rucong meucugek (: 59).

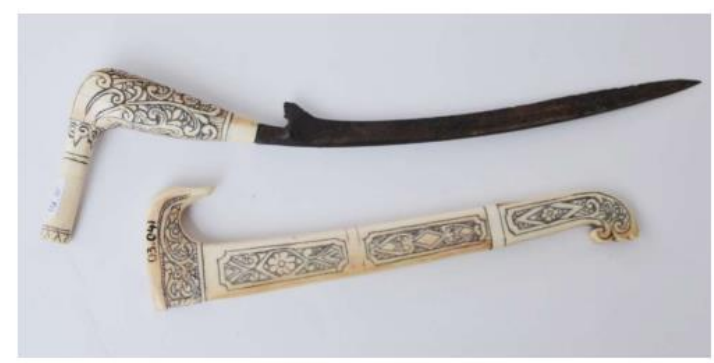

Figure 8. Aceh State Museum

Then according to Pinto, a Turkish adventurer (around 1540) mentioned that during the time of Sultan Al Kahhar, Aceh received 300 contributions from Turkey, this assistance was brought along with 4 Acehnese ships that came to Turkey to get war and develop weapons equipment (Rafi Abdillah, 2016: 57). So at this time, Rencong ornamental art has the support of experts and is experiencing good development in terms of rencong shape and design. In general, motifs that often appear are carved in the form of leaves or shapes of flowers, moon and sun stars.

The emergence of the development of design art, especially ornamental varieties during the Aceh Darussalam period was supported by the kingdom through a government policy known as 'Qanun'.

Historical sources that are rarely discussed in depth are Books az Tazkirat in Tabaqat Qanun Syara, Kingdom. Written by Shaykh Syamsu Al Bahri who is a great scholar of the era of Sultan Ali Mughayat Shah. In this book also contains 21 articles about people's obligations. Article 14 states that 'It is mandatory that all Acehnese learn and carve wood and carve stones with writing and flowers and print stones with sand and clay and limestone water and water (plant sap) and crushed bricks and crushed stones is all like that. (Deddy Satria, no. 2: 100).

The origin of the design of ornamental varieties and the origin of each motif comes from structural principles in the design of ornamental varieties that are closely related to the worldview of an artist or creator. According to Leight (1989), this worldview is shaped by a number of different factors including the network of blood relations, language, livelihoods, 
and religion. The cultural environment shapes feelings and perspectives so that people can judge various types of ornaments as beautiful forms, or must be considered, valuable, important or related to other factors in aspects of life. In Aceh, deep inspiration for Islam became a key element. Although the motive has continuity with the motives of the past, the most visible tendency is the incarnation of the Islamic view which is characterized by control and limitations of ornamental forms.

\section{Conclusion}

The history of design developments including the design of Aceh shows a dynamic movement. In Aceh, decorative ornaments find pre-Islamic motifs (old motifs) compiled so that they become Islamic. Islamic motifs and old patterns are often incorporated into one design. For example, royal crown motifs or sacred crowns are depicted with stars and crescent emblazoned on them and flanked by Arabic style, while triangles and rectangular shapes may originate from buds and lotus flowers that are widely known in Buddhism. On the other hand, Arabic letters or words in Arabic are often arranged into geometric shapes and floral motifs such as the letters lam and ha carved on the carved gravestones of houses and ornaments on mosques and Menasha.

The tendency of various aesthetic phenomena of Aceh's coastal decoration has a meaningful relationship with historical continuity, the connection in the search for cultural identity, and the process of balancing cultural values with Islamic identity as the main feature.

Cultural artifacts scattered in the form of Aceh Coastal handicrafts are seen in Sulam art, gold thread, Silk Weaving work, Tikam weapons, and carvings, especially wood carvings. Ornamental Varieties Aceh Ornamental Varieties can basically be divided into Pasai periods, transition periods or lamuri periods and ornamental varieties of Aceh (Darussalam). The golden period of Aceh's art was during the reign of Sultan Iskandar Muda (1607-1636) and Sultan Iskandar Thani (1636-1641). During this heyday, the Darud Dunya palace employed hundreds of artists, including spinners, add-ons, goldsmiths and blacksmiths and wood carvers. Artists are grouped and placed in various places in the city.

\section{References}

G. Eason, B. Noble, and I.N. Sneddon, (1955). "On certain integrals of Lipschitz-Hankel type involving products of Bessel functions," Phil. Trans. Roy. Soc. London, vol. A247, pp. 529-551.

J. Clerk Maxwell, (1892) A Treatise on Electricity and Magnetism, 3rd ed., vol. 2. Oxford: Clarendon, pp.68-73.

I.S. Jacobs and C.P. Bean, "Fine particles, thin films and exchange anisotropy," in Magnetism, vol. III, G.T. Rado and H. Suhl, Eds. New York: Academic, 1963, pp. 271350.

K. Elissa, "Title of paper if known," unpublished.

R. Nicole, "Title of paper with only first word capitalized," J. Name Stand. Abbrev., in press.

Y. Yorozu, M. Hirano, K. Oka, and Y. Tagawa, (1892) "Electron spectroscopy studies on magneto-optical media and plastic substrate interface," IEEE Transl. J. Magn. Japan, vol. 2, pp. 740-741.

M. Young, The Technical Writer's Handbook. Mill Valley, (1892) CA: University Science. 